\title{
Country of Origin and Consumers' Willingness to Pay: Study on Malaysian Organic Food Product
}

\author{
Siddique Ahmed, Chamhuri Siwar, A. S. A. Ferdous Alam, Basri Abdul Talib, Norshamliza \\ Chamhuri, Nor Diana Mohd Idris
}

\begin{abstract}
The two horrible conditions ahead of time than the organizers worldwide are to diminish the stack at the conventional fills and to reduce the continually developing basic spoiling. This test is proposed to discover probably the execution of the DI diesel motor at various loads when fuelled with mixes of palm methyl esters and diesel. The primers have been pushed on a completely utilized diesel motor without changes. Every one of the appraisals were consistent usa of america and outfitted toward dependable pace. The impact of moving weight develop to be assessed the volume that brake warm temperature ability, mass flow rate, brake one of a kind gas use and fumes gas temperature. Exploratory impacts show that at complete weight conditions, the B-20, B-40and B-60 mixes bring 33.23\%, 32.81\%, $32.39 \%$ and 31.ninety seven\% higher brake heat usefulness than sole diesel freely. It wound up confirmed that the brake warmth ability of palm biodiesel is higher than that of diesel, and it is a delayed consequence of the oxygenated atom of biodiesel which acknowledges total ingesting of the biodiesel fuel. In addition the mass development rate of biodiesel is evidently superior to anything that of diesel fuel; it is through method for exact capacity of the calorific estimation of biodiesel is a ton parcels less appeared in one another way as far as diesel gas. At the reason for results obtained from this test utilizing palm biodiesel as a fuel is proposed for the utilized as a piece of a diesel motor with diesel mixes.
\end{abstract}

Catchphrases: biodiesel, esterification, pyrolysis, emulsification, blends.

\section{INTRODUCTION}

In global marketing and consumer behavioral research, study on country of origin (COO) effect on consumers perception and buying behavior had been in the mainstream of research agenda for about last 50 years. During this

Revised Manuscript Received on April 19, 2019.

Siddique Ahmed, Institute for Environment and Development (LESTARI), Universiti Kebangsaan Malaysia (National University of Malaysia), 43600 UKM Bangi, Selangor, Malaysia, (Email drsiddiqueahmed@gmail.com)

Chamhuri Siwar, Institute for Environment and Development (LESTARI), Universiti Kebangsaan Malaysia (National University of Malaysia), 43600 UKM Bangi, Selangor, Malaysia, (Email csiwar@ukm.edu.my)

A. S. A. Ferdous Alam, School of International Studies, Universiti Utara Malaysia, 06010 UUM Sintok, Kedah, Malaysia, (Email ferdous@uum.edu.my)

Basri Abdul Talib, Faculty of Economics and Management, Universiti Kebangsaan Malaysia (National University of Malaysia), 43600 UKM Bangi, Selangor, Malaysia, (Email : basri@ukm.edu.my)

Norshamliza Chamhuri, Faculty of Economics and Management, Universiti Kebangsaan Malaysia (National University of Malaysia), 43600 UKM Bangi, Selangor, Malaysia, (Email : shamliza@ukm.edu.my)

Nor Diana Mohd Idris, Institute for Environment and Development (LESTARI), Universiti Kebangsaan Malaysia (National University of Malaysia), 43600 UKM Bangi, Selangor, Malaysia, (Email :nordiana@ukm.edu) period substantial research activities were able to build an clear understanding about effects of $\mathrm{COO}$, its cognitive process and its moderating and mediating factors (Thogersen et al, 2017). The 1960's researchers like Dicher (1962), Schooler (1965) and others were the pioneer to direct the researchers' interest to this direction. Most of the studies were carried on different food categories like poultry and dairy, meat, vegetables and fruits. Automotive and electronic products also got attention of researchers in $\mathrm{COO}$ studies. Considering the importance of $\mathrm{COO}$ the US and EU has enacted mandatory $\mathrm{COO}$ discloser on the food product label (Berry et al., 2015). COO serves as an influential cue in evaluating products quality around the globe. Research found that consumers associate the quality and/or other attributes of a particular product to a specific geographical location (Andéhn et al., 2016; Insch and Florek, 2009; Ahmed et al., 2004). This is because of the image, production process they follow and the legislation of that country. For instance in German market the countries with high competence in cheese production and cheese specialties command up to $43 \%$ premium (Schröck, 2014). COO simplifies the heuristic process of product evaluation in situations where other cues are complex to evaluate (Ahmed et al 2004). But COO effect vary depending on the product types under consideration (Balabanis and Diamantopoulos, 2004; Piron 2000, Roth and Romeo, 1992).

"Despite the growing importance of imported products in many organic food markets, only few studies have investigated the combined effect of $\mathrm{COO}$ and an organic label, or compared consumer preferences for one vs. other" (Thogersen, 2017). Among these few studies most are product specific (Chen et al., 2015) and/or comparison between domestic vs. imported organic foods (Schjoll, 2016; Xie et al., 2016; Schrock, 2014; Fledmann and Hamm 2015). For example, Chen (2015) investigated WTP for tomatoes carrying the European Union (EU) organic label and Chinese organic label and found that WTP is significantly higher for EU organic tomatoes than Chinese alternatives among Chinese consumers. Similar comparison was conducted by Wu et al., (2014) about the infant milk carrying organic label and result shows that US organic label is most preferred among EU, Chinese and US organic label. Janseen and Hamm (2012) analyzed consumer preferences and willingness-to-pay (WTP) for different 
organic logos in six European countries- Czech Republic, Denmark, Germany, Italy, Switzerland and United Kingdom. Using random parameter logit model they showed that WTP differ considerably among different organic logos.

The country of origin information of food products generally communicated through the phrase 'a product of...', or 'produced in...', 'grown in...', or by using logos indicating the origin of the product. The organic market share is very small in total food market. In Australia it is estimated to be approximately $1 \%$ (Henryks et. al., 2014) and $5.5 \%$ in United States (Organic Trade Association, 2018). Although the organic movement is pioneering in the developed countries, the demand for organic is increasing in the developing countries including Malaysia that is reflected in the rapid growth of the organic food chains. This growth may be attributed to the better understanding of the organic foods' features and benefits among the Malaysian consumers (Wong and Aini, 2017). The United Nation's report on 'World Economic Situation and Prospects 2018' identifies Malaysia as upper middle income country according to per-capita GNI (UN, 2018). With this increased GNI, Malaysians are now more conscious about their food and lifestyle choice. The growing demand for organic food in Malaysia is more than the local production (Mohamad et. al., 2014; Ahmad et. al., 2008) and about 60\% of organic food products are imported (Somasundram et al., 2016). About $70 \%$ of the organic food products is distributed through specialized organic food stores and supermarket chains and the balance is distributed through traditional retail shops, wet-markets or home deliveries (Stanton et al., 2011, as cited in Rezai et al., 2014, Phuah et al., 2015). Most of the organic fruits and vegetables are imported from Australia, Newzelland, China, Korea and Japan (Tiraieyari et al., 2014). Hence different country of origin organic products carrying different organic logos are available in Malaysian market and our real market observation also found these logos in organic outlets. We selected about 10 such logos for this study. Previous studies on organic food in Malaysia are concentrated on consumer perception, exploring factors and analyzing demographics. On the other hand COO study in Malaysia on imported food items are very few. In this sense it is the pioneering study in Malaysia as it combines effects of organic and COO. Therefore the current research investigates Malaysians consumers' perception on different country of origin organic logos and its effect on their willingness to pay (WTP).

\section{MATERIAL AND METHODS}

\section{Data gathering}

The study is based on the partial data gathered for a comprehensive study on organic vegetables and fruits and willingness-to-pay. The study was conducted through June 14 to August 14 of 2014. The 'Institute for Environment and Development' (LESTARI) of the National University of Malaysia (UKM) arranged the data collection under a project grant of the university. In this study self-selection purposive type sampling has been used (Hathaway et al., 2010; Robinson O C, 2014). The study was conducted among the citizen of Kualalumpur and some urban area of Selangor state of Malaysia. The cities in this survey include
Kualalumpur, Putrajaya, Kajang, and Bangi. About 500 questionnaires were distributed. Among those 342 returned. The response rate was $68.4 \%$ with 330 useable questionnaires. The respondents who reside near the organic shop or super shop selling organic product were selected for getting response. Some questionnaire were distributed and then collected and some data gathered through face to face interview. The participants were minimum adolescent and were solely or jointly responsible for the family's grocery shopping. Respondents were described the purpose of the survey and asked whether they know about organic product or not. Those who replied positively subsequently they were provided the questionnaire to answer if they agreed to participate in the survey. The demographic data is shown in the Appendix- A. The questionnaire items were divided into three parts; demographic, familiarity with organic logos and WTP. Demographic section included gender, age, marital status, nationality, ethnicity, occupation, place of residence, education, family size and income range. 'Familiarity with organic logos' section included ten dichotomous choice questionnaire with a pictorial presentation of ten organic logos including one regional logo (EU) and IFOAM logo (Figure-1). The logos under study were two Malaysian organic logos, two Australian organic logos, and one from each of USA, Newzelland, China and Japan. Although the IFOAM and EU organic logos are not from any specific country, we included them in this study because we want to know about whether the Malaysians are familiar with these two logos. In our subsequent analysis these two logos eventually dropped as they fail to form any component. Respondents were to choose either of the two options 'familiar' or 'not familiar' with the corresponding organic logo. In WTP section the respondents were asked six 5-point likert scale questions ( $1=$ strongly disagree and $5=$ strongly agree). The items are given in appendix- B. To suit the respondents with less proficiency in English language, a Bahasa Melayu (Malay language) version was also developed and used in the survey.

\section{Analysis and Results}

The study consists of three analytical steps. Step 1 is the summary of demographics and simple presentation of the status of organic logos among Malaysian consumers. Step 2 consists of principle component analysis (PCA) and multiple correspondence analysis (MCA) to visualize if there exists any similarities or hidden group among the variables. In addition of the continuous variable, PCA can be applied on binary and categorical variables if we consider the component as a latent factor (Lee, 2010; Takane \& Leeuw, 1987; Kamata \& Bauer, 2008; Ttnphns, 2017; Flounderer, 2015.) In step 3 a Pearson correlation matrix is constructed based on the composite scores of the $3 \mathrm{COO}$ categories and WTP following the method suggested by Song et al. (Song et al., 2013; Landgraf, \& Lee, 2015). The analyses were done with the help of Microsoft excel 2013 for step 1 and SPSS version 21 for step 2 and 3 .

The demography of the respondents is shown in 
appendix- A and the summary of the familiarity of organic logos are shown in figure- 2. Malaysians are most familiar to the domestic organic logos followed by USDA logo, Australian logos, Newzelland logo and EU organic logo. China organic logo is less familiar.

\section{Principal Component Analysis and Multiple Correspondence Analysis}

Principle component analysis (PCA) divided the 'organic logos' into 3 components dropping out 2 variables. The 2 variables are IFOAM logo and EU logo. As noted earlier these 2 logos are not from any specific country and failed to construct any component. The logos of Australia, Newzelland and USA constructed the first component, the logos of Japan and China constructed the second and the Malaysian organic logos constructed the third component. We named these three components as 'OECD COO', 'East Asian COO' and 'Malaysian COO' respectively. All variables of willingness-to-pay (WTP) constructed a single component with appropriate loadings and other indices. The items to measure the WTP is given in appendix-B. The variables and their loadings on each component, communality, percentage of variance explained, Eigen value and cronbach's coefficient have been shown in Table 1 .

\section{DISCUSSION}

As todays consumers are becoming increasingly more conscious about the origin of their foods and the ingredients the food contain, our findings have academic and business importance as it reflects the inner feelings of Malaysian consumers through the identification of COO. The findings indicate that responses towards the different organic logos followed a specific pattern that reflects the image in the mind of the Malaysian consumers about different countryof-origin organic logos. Principle component analysis (PCA) splits the organic logos into three components indicating Malaysian consumers grouped the logos into three categories, i.e. The OECD COO, East Asian COO and Malaysian COO (Figure-3). We got almost same grouping of organic logos, conducting a multiple corrospondence analysia (MCA) (Figure-4). This evidence suggests that perceptions of different $\mathrm{COO}$ are not homogenous. The logos fall in the same group are different from the other groups. However, this finding does not explain the reasons of why Malaysian consumers view these different country of origin logos differently.

Following this distinction among COO groups, we can attempt to find out the common characteristics of the countries falling in the same group. The OECD group can be characterised as the countries Malaysian trust most for their strong legislation of organic agriculture and appropriate implementation of organic practices. The consumers believe that the products from these countries actually complied with the organic standards. They are also confident that the producers and other actors of the supply chain are following the production and business ethics and all information related to organic products is revealed in the product label (Dardak et al, 2009). In matter of East-Asian COO, it is believed that in China and Japan there are some ethnic group who traditionally produce harbal and functional plants through a indigenous method of agriculture and consume regularly. Regulatory intervention is not necessary to compell them to practice this tradition. Probably this belief has been transferred to the organic products originating from these countries. Cultural similarities might be the another factor that bind the East-Asian $\mathrm{COO}$ in a single category.The distinction of Malaysian organic products can be characterized as lesser quality compared to others (Lew and Sulaiman, 2014). There is a lack of trust among Malaysian consumers in matter of quality standard of organic products even with government certification efforts. It seems that ethnocentrism is less effective in food choice, compromizing the quality standard in today's globalized world espicially in developing countries like Malaysia. This perception grew due to consumer's negative product experiences of locally made products ( Noor, 2005). But the scenerio is changing as the Malaysian producers are now being more concious about the quality of the local products to compete with the foreign products in local market.

The correlation result suggests that (Table-2) there is a significant negative correlation exists between the familiarity of Malaysian organic products and WTP and between OECD organic products and WTP. However, there is no correlation between East-Asian organic products and WTP. The Malaysians who are more familiar with the organic products originating from OECD countries as well as home countryare less likely to pay more and vice-varsa. Supirior quality of OECD organic products do not ensure higher WTP. The availability of organic products of OECD $\mathrm{COO}$ in the market make us believe that a group of consumers of urban area usually buy OECD products but general consumers do not support higher WTP of OECD products. WTP depends not only on the COO of the products but also on some other factors like affodability, convenience, subjective norms, food miles etc. In matter of Malaysian organic products, WTP also negatively correlated with Malaysian COO. Malaysian consumers have lack of confidence on the Malaysian organic food producers that they are actually following the organic standards. They have also lack of trust on the regulatory agencies that they are actually following the proper varification process. Anselmsson et al, (2014), Gao et al, (2014), and Loureiro and Umberger (2003) observed the similar finding in matter of country of origin labeling in other countries. On the contrary our finding differ from the finding of Ehmke, Lusk, and Tyner (2006) who found that consumer prefer food from their own country.

This finding partially support the findings of Janssen and Hamm (2012) and Magistris \& Gracia (2012) that WTP differ considerably between different organic logos and paying attention to organic labeling influences the intention to purchase organic food. Both studies were conducted in European countries. They suggested that well-known organic certification logos have a positive correlation with higher WTP. This difference in findings may be attributed to the difference in consumer characteristics and lifestyle of developed and developing countries. In an extensive literature review Newman et al. (2014) mensioned that 
"domestic food is mostly perceived to be safer and of higher quality, evaluated more positively and preferred more than imported food but these effects are occationally reversed in poorer and less developed countries". In China similar study (Walley et al 2014) suggest that food originating from overseas is perceived to be of higher quality than food originating from China and the Chinese consumers do not see food originating overseas as all the same but relate quality to the country from which it originates.

Although this COO study on organic food is pioneering in Malaysia, this study may lay some scope of critics. Firstly this study is not based on actual or controlled market condition rather the respondents provided their opinions seeing the organic logos in the questionnaire. Secondly it may lack representativeness for the whole Malaysia as the study was conducted in the Federal Territory of Malaysia ignoring the other provicial cities due to cost constraints. Another limitation is that the findings are based on selfreports and people may not actually do what they say they are doing.

\section{CONCLUSIONS}

Malaysia offer significant market potentials for organic food. As noted earlier that the combined effect of COO and organic food is a barren area of research and this is especially true in the context of developing countries like Malaysia where both study on $\mathrm{COO}$ and organic products has a number of issues yet to be addressed by the researchers. Despite some limitations the study has generated a new dimension of COO study regarding organic food market of Malaysia. Specifically Malaysian organic food market may be segmented into 3 categories based on country-of-origin: OECD, East Asia and Malaysian COO. These segmentation may very well represent an opportunity for the overseas food producers but these segmentations should carefully analyzed before marketing of organic food because the effective monetary WTP for these categories are yet to be confirmed. Although Malaysians are more familiar with domestic organic logos, they hold a different approach to foreign organic logos and they see OECD organic logos, East-Asian organic logos and Malaysian organic logos as three distinct categories; but this distinct categorization do not necessarily translated into higher WTP. Our findings may derive new thinking from the part of different actors of global organic food market to seek competitive advantages. It also has an implication in formulating product labeling strategy and designing appropriate marketing policy including advertising for organic food.

\section{ACKNOWLEDGEMENT}

Authors are very grateful and would like to acknowledge Emeritus Prof. Chamhuri Siwar and Dr. Nor Diana Mohd Idris for funding support from project Arus Perdana (AP2014-017) and (GGPM-2018-040) granted by Universiti Kebangsaan Malaysia (National University of Malaysia), Bangi, Selangor, Malaysia.

\section{REFERENCES}

1. Ahmad, S.N.B. and Juhdi, N., July, 2008. "Consumer's perception and purchase intentions towards organic food products: Exploring the attitude among Malaysian consumers". In 16th Annual Conference on Pacific Basin Finance, Economics, Accounting and Management, Brisbane, Australia.

2. Ahmed, Z.U., Johnson, J.P., Yang, X., Kheng Fatt, C., Sack Teng, H. and Chee Boon, L., 2004. "Does country of origin matter for low-involvement products?" International Marketing Review, Vol. 21 No. 1, pp.102-120.

3. Andéhn, M., Nordin, F. and Nilsson, M.E., 2016. "Facets of country image and brand equity: Revisiting the role of product categories in country-of-origin effect research". Journal of Consumer Behaviour, Vol. 15 No. 3, pp.225-238.

4. Anselmsson, J., Vestman Bondesson, N. and Johansson, U., 2014. "Brand image and customers' willingness to pay a price premium for food brands". Journal of Product \& Brand Management, Vol. 23 No. 2, pp.90102.

5. Balabanis, G. and Diamantopoulos, A., 2004. "Domestic country bias, country-of-origin effects, and consumer ethnocentrism: a multidimensional unfolding approach". Journal of the Academy of Marketing Science, Vol. 32 No. 1, pp.80-92.

6. Berry, C., Mukherjee, A., Burton, S. and Howlett, E., 2015. "A COOL effect: The direct and indirect impact of country-of-origin disclosures on purchase intentions for retail food products". Journal of Retailing, Vol. 91 No. 3, pp.533-542.

7. Chen, M., Yin, S., Xu, Y. and Wang, Z., 2015. "Consumers' willingness to pay for tomatoes carrying different organic labels: Evidence from auction experiments". British Food Journal, Vol. 117 No. 11, pp.2814-2830.

8. Dardak, R.A., Abidin, A.Z.Z. and Ali, A.K., 2009. "Consumers' perception, consumption and preference on organic product: Malaysian Perspective". Economic and Technology Management Review, Vol. 4, pp.95-107.

9. Dichter, E. (1962), "The world customer". The International Executive, Vol. 4 No. 4, pp.25-27.

10. Ehmke, M.T., Lusk, J. and Tyner, W., 2006, August. "The relative importance of preferences for country-oforigin in China, France, Niger and the United States". In Contributed paper presented at the International Association of Agricultural Economists Conference, Gold Coast, Australia.

11. Feldmann, C. and Hamm, U., March, 2015. "Consumers' perceptions and preferences for local food: A review". Food Quality and Preference, Vol. 40, pp.152164.

12. Flounderer

(https://stats.stackexchange.com/users/13818/flounderer), 2015. Would PCA work for boolean (binary) data types?, URL (version: 2015-07-03) https://stats.stackexchange.com/q/159731

13. Gao, Z., Sing Wong, S., A. House, L. and H. Spreen, T., 2014. "French consumer perception, preference of, and willingness to pay for fresh fruit based on country of origin”. British Food Journal, Vol. 116 No.5, pp.805820.

14. Hathaway, A.D., Hyshka, E., Erickson, P.G., Asbridge, M., Brochu, S., Cousineau, M.M., Duff, C. and Marsh, D., 2010. "Whither RDS? An investigation of respondent 
driven sampling as a method of recruiting mainstream marijuana users". Harm reduction journal, Vol. 7 No. 1 , p.15.

15. Henryks, J., Cooksey, R. and Wright, V., 2014. "Organic food at the point of purchase: Understanding inconsistency in consumer choice patterns". Journal of Food Products Marketing, Vol. 20 No. 5, pp.452-475.

16. Insch, A. and Florek, M., 2009. "Prevalence of country of origin associations on the supermarket shelf". International Journal of Retail \& Distribution Management, Vol. 37 No. 5, pp.453-471.

17. Janssen, M. and Hamm, U., 2012. "Product labelling in the market for organic food: Consumer preferences and willingness-to-pay for different organic certification logos". Food quality and preference, Vol. 25 No. 1, pp.922 .

18. Kamata, A., \& Bauer, D. J. (2008). A note on the relation between factor analytic and item response theory models. Structural Equation Modeling: A Multidisciplinary Journal, 15(1), 136-153.

19. Landgraf, A. J., \& Lee, Y. (2015). Dimensionality reduction for binary data through the projection of natural parameters. arXiv preprint arXiv:1510.06112.

20. Lee, S. (2010). Principal components analysis for binary data(Doctoral dissertation, Texas A \& M University).

21. Lew, S. and Sulaiman, Z., 2014. "Consumer purchase intention toward products made in Malaysia vs. made in China: A conceptual paper". Procedia-Social and Behavioral Sciences, Vol. 130, pp.37-45.

22. Loureiro, M.L. and Umberger, W.J., 2003. "Estimating consumer willingness to pay for country-of-origin labeling". Journal of Agricultural and Resource Economics, Vol. 28, pp.287-301.

23. Magistris, T. and Gracia, A., 2012. "Do consumers pay attention to the organic label when shopping organic food in Italy?" In Organic Food and Agriculture-New Trends and Developments in the Social Sciences. InTech.

24. Mohamad, S.S., Rusdi, S.D. and Hashim, N.H., 2014. "Organic food consumption among urban consumers: preliminary results". Procedia-Social and Behavioral Sciences, Vol. 130, pp.509-514.

25. Newman, C.L., Turri, A.M., Howlett, E. and Stokes, A., 2014. Twenty years of country-of-origin food labeling research: a review of the literature and implications for food marketing systems. Journal of Macromarketing, Vol. 34 No.4, pp.505-519.

26. Noor, J.M., 2005. "The Consumers' Perception on the Quality of Malaysian Made Electrical Products Design" (Doctoral dissertation, University Putra Malaysia).

http://psasir.upm.edu.my/id/eprint/6179/1/FRSB_2005_3 (1-24).pdf, Retrieved on August 11, 2018.

27. Organic Trade Association, 2018. "US Organic Industry Survey 2018". https://ota.com/resources/organicindustry-survey. Retrived on October 11, 2018.

28. Phuah, K.T., Rezai, G., Mohamed, Z. and Shamsudin, M.N., 2015. "Socio-Demographic Profile in Purchasing Malaysia". International Journal of Social Science and Humanity, Vol. 5 No. 7, p.604-607.

29. Piron, F., 2000. "Consumers' perceptions of the countryof-origin effect on purchasing intentions of (in) conspicuous products". Journal of Consumer Marketing, Vol. 17 No. 4, pp.308-321.

30. Rezai, G., Kit Teng, P., Mohamed, Z. and Shamsudin, M.N., 2014. "Structural equation modeling of consumer purchase intention toward synthetic functional foods". Journal of Food Products Marketing, Vol. 20 No. sup1, pp.13-34.

31. Robinson, O.C., 2014. "Sampling in interview-based qualitative research: A theoretical and practical Natural and Synthetic Functional Foods in

guide". Qualitative research in psychology, Vol. 11 No. 1 , pp.25-41

32. Roth, M.S. and Romeo, J.B., 1992. "Matching product catgeory and country image perceptions: A framework for managing country-of-origin effects". Journal of international business studies, Vol. 23 No. 3, pp.477497.

33. Somasundram, C., Razali, Z. and Santhirasegaram, V., 2016. "A Review on organic food production in Malaysia". Horticulturae, Vol. 2 No. 3, pp.12-18.

34. Schjøll, A., 2017. "Country-of-origin preferences for organic food". Organic Agriculture, Vol. 7 No. 3, pp.315-327.

35. Schooler, R.D., 1965. "Product bias in the Central American common market". Journal of marketing research, Vol. 2, No. November, 1965, pp.394-397.

36. Schröck, R., 2014. "Valuing country of origin and organic claim: a hedonic analysis of cheese purchases of German households". British Food Journal, Vol. 116 No. 7, pp.1070-1091.

37. Song, M. K., Lin, F. C., Ward, S. E., \& Fine, J. P. (2013). Composite variables: when and how. Nursing research, 62(1), 45-9.

38. Takane, Y., \& De Leeuw, J. (1987). On the relationship between item response theory and factor analysis of discretized variables. Psychometrika, 52(3), 393-408

39. Thøgersen, J., Pedersen, S., Paternoga, M., Schwendel, E. and Aschemann-Witzel, J., 2017. "How important is country-of-origin for organic food consumers? A review of the literature and suggestions for future research". British Food Journal, Vol. 119 No. 3, pp.542557. [crossreferenced]

40. Tiraieyari, N., Hamzah, A. and Samah, B.A., 2014 "Extension Agents and Sustainable Cocoa Farming: A Case Study of Extension Agents in Sabah State, Malaysia". Modern Applied Science, Vol. 8 No. 6, pp.210-218.

41. Ttnphns (https://stats.stackexchange.com/users/3277/ttnphns), 2017. "Doing principal component analysis or factor analysis on binary data", URL (version: 2017-08-19): https://stats.stackexchange.com/q/16335

42. UN, 2018. "World Economic Situation and Prospects 2018- Joint report of UN-DESA, UNCTAD and the five UN regional commissions". https://www.un.org/development/desa/dpad/wp content/uploads/sites/45/publication/WESP2018_Full_W eb-1.pdf, pp.118-120. Retrieved on September 28, 2018.

43. Walley, K., Custance, P., Feng, T., Yang, X., Cheng, L. and Turner, S., 2014. "The influence of country of origin on Chinese food consumers". Transnational Marketing Journal, Vol. 2 No. 2, pp.78-98

44. Wong, S.S. and Aini, M.S., 2017. "Factors influencing purchase intention of organic meat among consumers in Klang Valley, Malaysia”. International Food Research Journal, Vol. 24 No. 2, pp.767-778.

45. Wu, L., Yin, S., Xu, Y. and Zhu, D., 2014. "Effectiveness of China's organic food certification policy: consumer preferences for infant milk formula with different organic certification labels". Canadian Journal of Agricultural Economics, Vol. 62 No. 4, pp.545-568.

46. Xie, J., Gao, Z., Swisher, M. and Zhao, X., 2016. "Consumers' preferences for fresh broccolis: interactive effects between country of origin and organic labels". Agricultural Economics, Vol. 47 No. 2, pp.181191 
International Conference on Recents Advancements in Engineering and Technology (ICRAET-18) |15th and 16th March 2019|Siddhartha Institute of Technology \& Sciences, Telangana, India.

\begin{tabular}{|c|c|c|c|c|}
\hline $\begin{array}{l}\text { GANIK MM } \\
\text { SOM, Malaysia }\end{array}$ & OAM, Malaysia & EU Organic Logo & 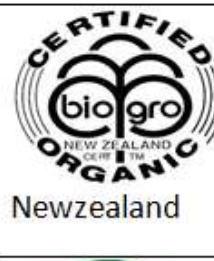 & $\begin{array}{l}\text { NASAA } \\
\text { Nasaa, Australia }\end{array}$ \\
\hline USDA, USA & $\begin{array}{l}\text { (S) AUSTRALIAN } \\
\text { AuRTIFIED } \\
\text { ORGANIC } \\
\text { Australia }\end{array}$ & $\begin{array}{l}\text { Int. Federation of } \\
\text { Organic Agricultural } \\
\text { Movement Logo }\end{array}$ & $\begin{array}{l}\text { China Organic } \\
\text { Logo }\end{array}$ & $\begin{array}{l}\text { Japanese Organic } \\
\text { Agriculture Standard }\end{array}$ \\
\hline
\end{tabular}

Fig. 1 Organic Logos Used in This Study

\section{Familiarity with Organic logos}

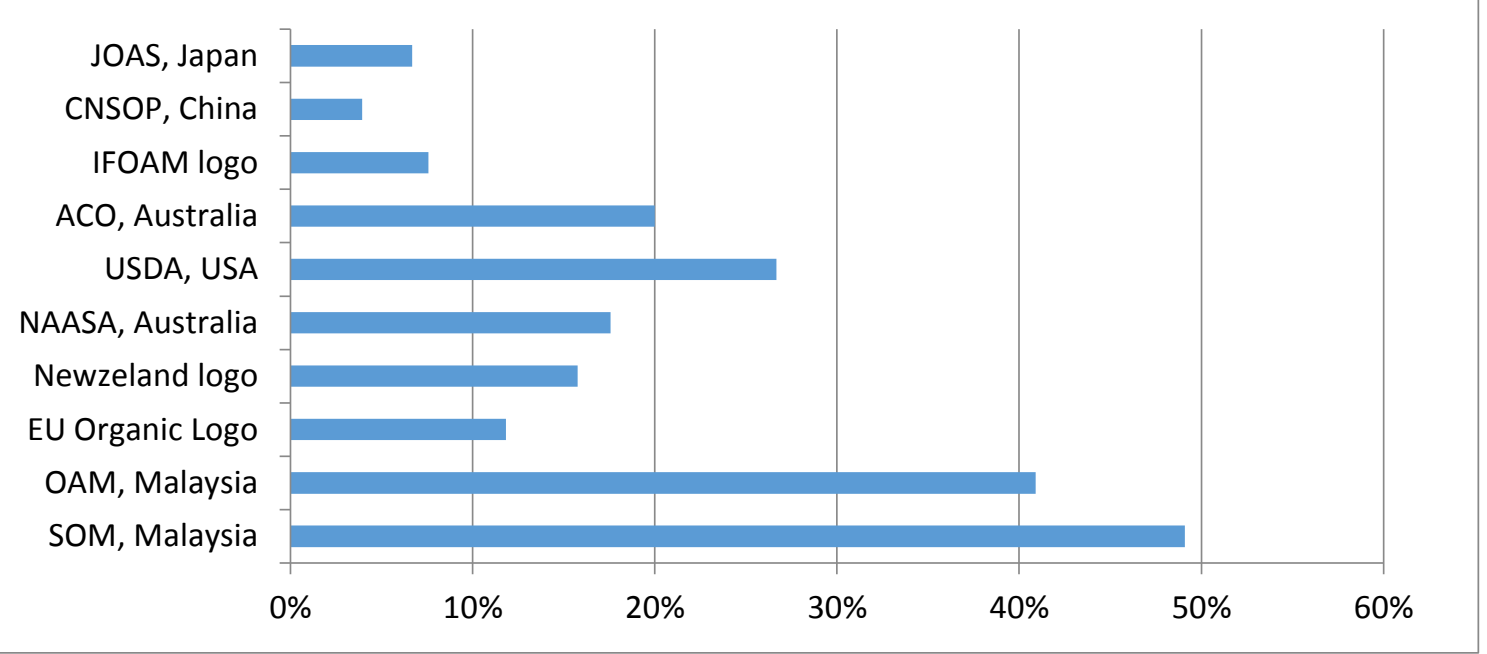

Fig. 2. Familiarity of 10 Different Organic Logos among Malaysian Consumers

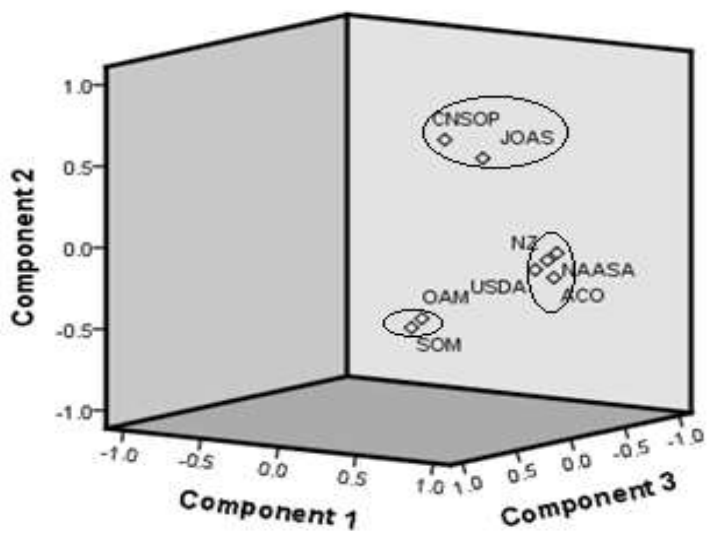

Fig 3: Component Plots of Organic Logos

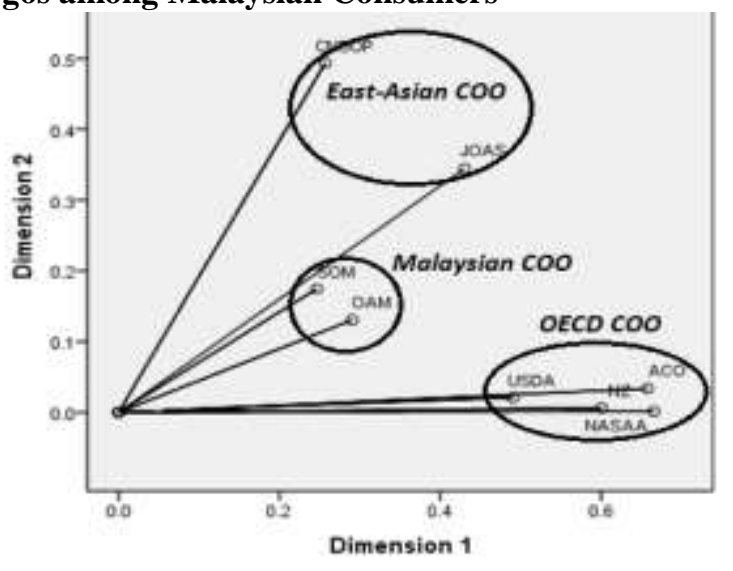

Variable Principat Nomakization

Fig. 4. Discriminant Measure of Multiple Correspondence Analysis

Table 1. Result of Principal Component Analysis

\begin{tabular}{ccccccc}
\hline \multirow{2}{*}{ Factor Name } & Item & $\begin{array}{c}\text { Item } \\
\text { Loading }\end{array}$ & $\begin{array}{c}\text { Commun } \\
\text { ality }\end{array}$ & $\begin{array}{c}\text { \% of Variance } \\
\text { (Cumulative) }\end{array}$ & $\begin{array}{c}\text { Eigen } \\
\text { Value }\end{array}$ & $\begin{array}{c}\text { Cronbach's } \\
\text { Coefficient }\end{array}$ \\
\hline \multirow{2}{*}{ WTP } & WTP5 & 0.882 & 0.786 & $30.741(30.741)$ & 4.304 & 0.918 \\
& WTP3 & 0.864 & 0.75 & & & \\
& WTP4 & 0.857 & 0.741 & & &
\end{tabular}




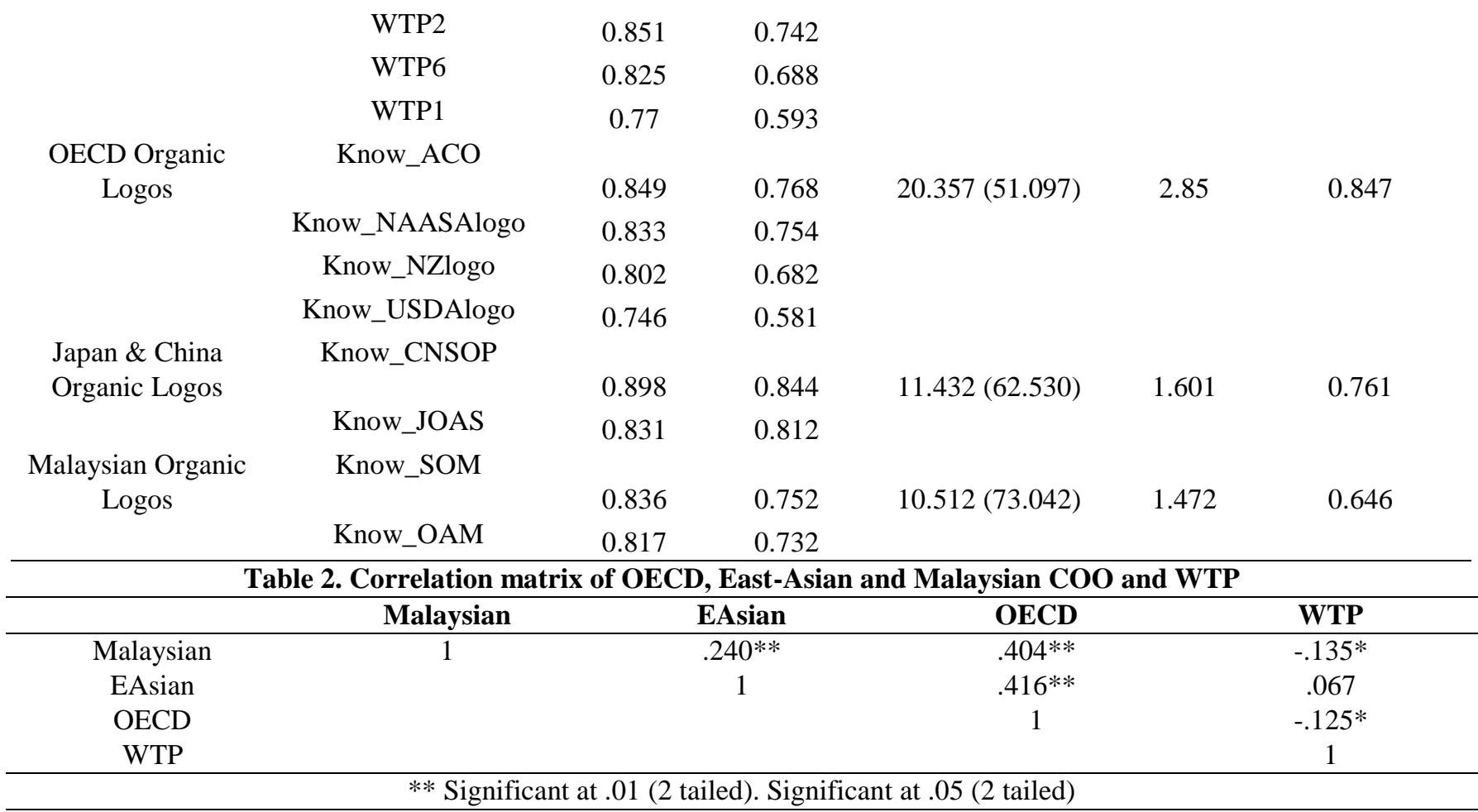

1. Appendix - A

Demographic Characteristics of the Respondents

\begin{tabular}{|c|c|c|c|c|c|c|c|}
\hline & & $\mathbf{n}$ & $\%$ & & & $\mathbf{n}$ & $\%$ \\
\hline \multirow[t]{2}{*}{ Gender } & Male & 110 & $33.33 \%$ & \multirow[t]{5}{*}{$\begin{array}{l}\text { Place of } \\
\text { Residence }\end{array}$} & Kajang & 89 & $26.97 \%$ \\
\hline & Female & 220 & $66.67 \%$ & & Bangi & 58 & $17.58 \%$ \\
\hline \multirow[t]{5}{*}{ Age $(M=35)$} & $18-27$ & 75 & $22.73 \%$ & & Putrajaya & 40 & $12.12 \%$ \\
\hline & $28-37$ & 150 & $45.45 \%$ & & Kualalumpur & 88 & $26.67 \%$ \\
\hline & $38-47$ & 60 & $18.18 \%$ & & Others & 55 & $16.67 \%$ \\
\hline & $48-57$ & 29 & $8.79 \%$ & Education & Primary & 11 & $3.33 \%$ \\
\hline & $58-67$ & 16 & $4.85 \%$ & & Secondary & 67 & $20.30 \%$ \\
\hline \multirow[t]{4}{*}{ Marital status } & Single & 129 & $39.09 \%$ & & Diploma & 41 & $12.42 \%$ \\
\hline & Maried & 192 & $58.18 \%$ & & Graduate & 80 & $24.24 \%$ \\
\hline & Divorced & 6 & $1.82 \%$ & & Post-graduate & 131 & $39.70 \%$ \\
\hline & Widowed & 3 & $0.91 \%$ & Family Size & 1 to 3 & 124 & $37.58 \%$ \\
\hline \multirow[t]{2}{*}{ Nationality } & Malaysian & 323 & $97.88 \%$ & & 4 to 6 & 152 & $46.06 \%$ \\
\hline & Others & 7 & $2.12 \%$ & & 7 to 9 & 42 & $12.73 \%$ \\
\hline \multirow[t]{4}{*}{ Ethnic } & Melayu & 230 & $69.70 \%$ & & 10 to 12 & 12 & $3.64 \%$ \\
\hline & Chinese & 35 & $10.61 \%$ & $\begin{array}{l}\text { Monthly } \\
\text { Income }\end{array}$ & $\begin{array}{l}\text { Less than RM } \\
3000\end{array}$ & 182 & $55.15 \%$ \\
\hline & Indian & 28 & $8.48 \%$ & & $\begin{array}{l}\text { RM 3001 - RM } \\
10000\end{array}$ & 126 & $38.18 \%$ \\
\hline & Others & 37 & $11.21 \%$ & & $\begin{array}{l}\text { RM } 10001 \text { - } \\
\text { RM } 20000\end{array}$ & 22 & $6.67 \%$ \\
\hline \multirow[t]{5}{*}{ Occupation } & University Teacher & 75 & $22.73 \%$ & & & & \\
\hline & Govt. Job & 70 & $21.21 \%$ & & & & \\
\hline & Private Job & 112 & $33.94 \%$ & & & & \\
\hline & Self Employed & 44 & $13.33 \%$ & & & & \\
\hline & Others & 29 & $8.79 \%$ & & & & \\
\hline
\end{tabular}


International Conference on Recents Advancements in Engineering and Technology (ICRAET-18) |15th and 16th March 2019|Siddhartha Institute of Technology \& Sciences, Telangana, India.

2. Appendix - B

6 questions for measuring WTP

\begin{tabular}{ll}
\hline Coding & Questions \\
\hline WTP1 & I am willing to purchase organic foodeven if the price is higher. \\
WTP2 & I am willing to buy organic vegetables and fruits even though choices are limited. \\
WTP3 & I would still buy organic vegetables and fruits even though conventional altematives are on sale. \\
WTP4 & Buying organic vegetables and fruits is the right thing to do evenif they cost more. \\
WTP5 & I am willing to buy organic vegetables and fruits because the benefits I get are more than the cost I pay. \\
WTP6 & I do not mind spendingmore time sourcing for organic vegetables and fruits.
\end{tabular}

